\title{
Identification and Characterization of Proteins in Sarcoplasmic Reticulum from Normal and Failing Human Left Ventricles
}

\author{
Matthew A. Movsesian ${ }^{1}$, Cynthia Leveille ${ }^{2}$, Judith Krall'1, John Colyer $^{3}$, \\ Jerry H. Wang ${ }^{3}$ and Kevin P. Campbell ${ }^{2}$
}

\author{
${ }^{1}$ Cardiology Division, University of Utah Medical Center, Salt Lake City, Utah, US A, ${ }^{2}$ Howard Hughes \\ Medical Institute and Department of Physiology and Biophysics, University of Iowa, Iowa City, Iowa, \\ USA, ${ }^{3}$ Cell Regulation Group, Faculty of Medicine, University of Calgary, Calgary, Alberta, Canada
}

(Received 21 November 1989, accepted in revised form 29 June 1990)

\begin{abstract}
M. A. Movsesian, C. Leveille, J. Krall, J. Colyer. J. H. Wang and K. P. Campbell. Identification and Characterization of Proteins in Sarcoplasmic Reticulum from Normal and Failing Human Left Ventricles. Journal of Molecular and Cellular Cardiology (1990) 22, 1477-1485. Monoclonal and polyclonal antibodies to the major Sarcoplasmic reticulum proteins of rabbit skeletal and canine cardiac muscle have been used to identify and characterize the corresponding components of human cardiac Sarcoplasmic reticulum. The $\mathrm{Ca}^{2+}$ transporting ATPase of human cardiac Sarcoplasmic reticulum was identified as a 105000-Ua protein antigenically distinct from its rabbit skeletal muscle counterpart. Human cardiac Sarcoplasmic reticulum also contained 53000-155000- and 165000-Da glycoproteins antigenically related to the low and high molecular weight glycoproteins of canine cardiac and rabbit skeletal muscle Sarcoplasmic reticulum. The ryanodinesensitive $\mathrm{Ca}^{2+}$ channel of human cardiac Sarcoplasmic reticulum was identified as a 400000 -Da protein antigenically related to its counterparts in canine cardiac and rabbit skeletal muscle. Human cardiac calsequestrin was identified as a $52000-\mathrm{Da}$ protein. Human phospholamban was identified as a $29000-\mathrm{Da}$ substrate for phosphorylation by cAMP-dependent protein kinase.

Immunoblots of Sarcoplasmic reticulum from the normal left ventricles of four unmatched organ donors and the excised failing left ventricles of nine patients with idiopathic dilated cardiomyopathy were compared in search of qualitative differences in the protein patterns of the failing hearts. No such differences were found with respect to the $\mathrm{Ca}^{2+}$ ATPase, the $53000-\mathrm{Da}$ glycoprotein, the ryanodine-sensitive $\mathrm{Ca}^{2+}$ channel, calsequestrin or phospholamban. In contrast, the $165000-\mathrm{Da}$ glycoprotein band, present in all four preparations from nonfailing hearts, was absent from three of nine preparations from failing hearts, and staining of the 55000-Da glycoprotein in these three preparations appeared to be relatively increased. The absence of the $155000-\mathrm{Da}$ glycoprotein band may identify or reflect a pathogenetic mechanism in a subset of patients with idiopathic dilated cardiomyopathy.
\end{abstract}

KEY Words: Sarcoplasmic reticulum; Cardiomyopathy; $\mathrm{Ca}^{2+}$ ATPase; Ryanodine-sensitive $\mathrm{Ca}^{2+}$ channel; Calsequestrin; Glycoproteins; Phospholamban; Heart failure; Cardiomyopathy.

\section{Introduction}

Heart failure is accompanied by abnormal intracellular $\mathrm{Ca}^{2+}$ handling in human myocardium (Gwathmey et al., 1987), raising the possibility that alterations in the molecular mechanisms of $\mathrm{Ca}^{2+}$ uptake, binding and release by the sarcoplasmic reticulum might be involved (either directly or indirectly) in the pathophysiology of this condition, Until now, however, the identification and characterization of the proteins involved in these processes and the mechanisms through which these processes occur has been carried out in sarcoplasmic reticulum prepared from non-human sources, and the extent to which observations made in these preparations apply to humans is unclear. These considerations seem particularly important in view of recent studies demonstrating significant differences in the biochemical characteristics of dilated cardiomyopathy in humans and in animal models. In the latter, decreased $\mathrm{Ca}^{2+}$ uptake by cardiac sarcoplasmic reticulum has been observed in both crude tissue homogenates

Please address all correspondence to: Matthew Movsesian, Cardiology Division, University of Utah Medical Center, 50 North Medical Drive, Salt Lake City, UT 84132, USA. 
and isolated microsomal preparations (Whitmeretal., 1988). In humans, in contrast, $\mathrm{Ca}^{2+}$ uptake is decreased in crude tissue homogenates but not in isolated microsomal preparations (Limas et al., 1987; Movsesian et al., 1989; Movsesian et al., 1990). These differences suggest that the human and animal diseases result from separate pathogenic mechanisms, and make clear the need for direct studies using human tissue.

The increase in the number of cardiac transplantations performed in recent years has made it possible to carry out such studies. In this paper, we describe our use of monoclonal and polyclonal antibodies that bind to the major proteins of rabbit skeletal and canine cardiac muscle sarcoplasmic reticulum to identify and characterize the corresponding protein constituents of human cardiac sarcoplasmic reticulum. In addition, we have used these antibodies to compare protein patterns in sarcoplasmic reticulum prepared from normal human left ventricles and from the left ventricles of patients with idiopathic dilated cardiomyopathy.

\section{Materials and Methods}

\section{Preparation of sarcoplasmic reticulum}

Skeletal muscle triads were isolated from adult rabbit muscle according to Mitchell et al. (1983), as modified by Sharp et al. (1987), in the presence ofaprotinin $(76.8 \mathrm{nM})$, benzamidine $(0.83 \mathrm{mM})$, iodoacetamide $(1 \mathrm{mM})$, leupeptin $(1.1(\mu \mathrm{M})$, pepstatin $\mathrm{A}(0.7 \mu \mathrm{M})$, and phenylmethylsulfonyl fluoride (PMSF, 0.23 $\mathrm{mM})$. Canine cardiac microsomes were prepared according to Jones and Cala (1981) in the presence of protease inhibitors. Bovine cardiac microsomes were prepared according to Suzuki and Wang (1986). Membranes were stored at $-135^{\circ} \mathrm{C}$ in $0.25 \mathrm{M}$ sucrose, $10 \mathrm{~mm}$ histidine ( $\mathrm{pH} 7.4), 0.83 \mathrm{~mm}$ benzamidine, 1 $\mathrm{mM}$ iodoacetamide and $58 \mu \mathrm{M}$ PMSF.

Human cardiac sarcoplasmic reticulum was prepared from normal and failing left ventricular free wall tissue according to Movsesian et al. (1989). Normal left ventricular tissue was obtained from kidney donors aged 17-40 years with no evidence of cardiac disease who had suffered trauma-related brain death and had been maintained on ventilators for 2-5 days prior to tissue procurement. No suitable recipients for these hearts were identified. Failing left ventricular tissue was obtained from the excised hearts of transplant recipients with Class IV heart failure resulting from idiopathic dilated cardiomyopathy. The $\beta$-adrenergic receptor density in crude sarcolemmal preparations was $110.0 \pm 15.3$ $\mathrm{fmol} / \mathrm{mg}$ in the normal hearts and $52.1 \pm 4.5$ $\mathrm{fmol} / \mathrm{mg}$ in the failing hearts. Hearts were excised following infusion of cold cardioplegia solution into the root of the cross-clamped aorta and maintained at $4^{\circ} \mathrm{C}$ until preparation of microsomes. The time between cardiac excision and homogenization was less than $2.5 \mathrm{~h}$ in the case of normal hearts procured at distant locations and less than $0.5 \mathrm{~h}$ in the case of normal and failing hearts procured locally (all failing hearts were procured locally). Preparations from normal and failing hearts had been compared with respect to $\mathrm{Ca}^{2+}$ uptake activity and phospholipid: protein ratios as previously described (Movsesian et al., 1989). values for $V_{\max }, K_{0.5}$ and nniii in the preparations from normal ventricles were $593 \mathrm{nmol} / \mathrm{mg}$-min, $0.68 \mu \mathrm{M}$, and 1.7 , respectively. The corresponding values in the preparations from failing ventricles were $593 \mathrm{nmol} / \mathrm{mg}-\min , 0.63 \mu \mathrm{M}$ and 1.6. The phospholipid:protein ratio (nmol phosphate per $\mathrm{mg}$ protein) was $35.3 \pm 4.0$ in preparations from normal hearts and $34.1 \pm 2.4$ in preparations from failing hearts. Studies with monoclonal antibodies have shown no differences between the two sets of preparations with regard to phospholamban-mediated stimulation of $\mathrm{Ca}^{2+}$ uptake (Movsesian et al., 1990).

\section{Preparation of antibodies}

Monoclonal antibodies (IID8, Al) against the canine cardiac sarcoplasmic reticulum ATPase and phospholamban were prepared as previously described (Jorgensen et al., 1988; Suzuki and Wang, 1986). Monoclonal antibody (XIIC4) to rabbit skeletal muscle sarcoplasmic reticulum glycoproteins was prepared using the procedures described for the preparation of anti-ryanodine-sensitive $\mathrm{Ca}^{2+}$ channel antibodies from mice immunized with sarcoplasmic reticulum vesicles (Campbell and MacLennan, 1981). Polyclonal antibodies (GP-3) to the purified ryanodine receptor have been previously prepared (Hoff- 
man et al., 1987) using guinea pigs immunized with gel slices of the purified 450 000-Da rabbit skeletal muscle ryanodine receptor according to the method of Tung (1983). Polyclonal antibodies (rabbit A) to calsequestrin have been previously prepared using rabbits immunized with gel slices of the purified canine cardiac calsequestrin (Campbell et al., 1983; Jorgensen and Campbell, 1984). The specificity of the various antibodies was determined by immunodot, immunoblot and immunoprecipitation assays as described (Campbell et al., 1987; Leung et al., 1988).

\section{Immunostaining of Western blots}

Sarcoplasmic reticulum membranes (5-60 $\mu \mathrm{g}$ ) were solubilized in sample buffer $(130 \mathrm{mM}$ Tris(hydroxymethyl)aminomethane $\mathrm{HCl}$ (Tris-HCl, pH 6.8), 1 M sucrose, 6\% sodium dodecyi sulfate (SDS), 0.002\% bromophenol blue and $200 \mathrm{~mm}$ DT'T) and electrophoresed on $3-12 \%$ polyacrylamide gels (with $3 \%$ stacking gels) as described by Laemmli (1970). Following electrophoresis for $15 \mathrm{~h}$ at $50 \mathrm{~V}$, proteins were transferred electrophoretically to nitrocellulose paper in $25 \mathrm{~mm}$ Tris, $195 \mathrm{mM}$ glycine, and $20 \%$ methanol at $100 \mathrm{~V}$ for 90 min at $4{ }^{\circ} \mathrm{C}$ according to the method of Towbin et al. (1979). The nitrocellulose blots were first dried and then incubated in buffer containing $10 \mathrm{mM}$ Tris- $\mathrm{HCl}\left(\mathrm{pH} 7.4,25^{\circ} \mathrm{C}\right), 0.5 \mathrm{M}$ $\mathrm{NaCl}, 0.05 \%$ Tween-20, and $0.5 \%$ nonfat dry milk ("buffer A") for $1 \mathrm{~h}$ to block excess binding sites. Blots were then incubated in buffer $A$ in the presence of 1:1000 dilutions of monoclonal or polyclonal antibodies to $\mathrm{Ca}^{2+}$ ATPase, calsequestrin, ryanodine-sensitive $\mathrm{Ca}^{2+}$ channel and 53 000-Da and $165000-\mathrm{Da}$ glycoproteins at room temperature under gentle rocking for $16 \mathrm{~h}$. Blots were washed twice for $10 \mathrm{~min}$ in buffer $\mathrm{A}$ to remove excess unbound antibody and then incubated for $1 \mathrm{~h}$ in buffer A containing the appropriate secondary antibody (goat anti-mouse and anti-rabbit IgG-peroxidase conjugates or rabbit and antiguinea-pig $\operatorname{IgG}$ peroxidase conjugate) at room temperature for $1 \mathrm{~h}$. Blots were washed twice with buffer $A$ again and then developed using 4-chloro-l-naphthol as the substrate.

These procedures were modified in immunostains ofphospholamban. Gradient gels were $10-20 \%$ polyacrylamide, and electrophoretic transfer was performed at $25 \mathrm{~V}$ for $6.5 \mathrm{~h}$. The concentration of anti-phospholamban antibody used in staining was $2.5 \mu \mathrm{g} / \mathrm{ml}$.

\section{Endo- $\beta$-N-acetylglucosaminidase $H$ digestion of car- diac sarcoplasmic reticulum}

High mannose oligosaccharide chains were removed from cardiac sarcoplasmic reticulum glycoproteins with endo- $\beta$-N-acetylglucosaminidase $\mathrm{H}$ (endo $\mathrm{H}$ ) as previously described (Campbell et al., 1983). Cardiac sarcoplasmic reticulum (25 $\mu \mathrm{g})$ was solubilized with $5 \mu \mathrm{l}$ of $10 \%$ SDS. The SDS-solubilized samples were boiled for $30 \mathrm{~s}$ and then cooled and diluted with $100 \mu \mathrm{l}$ of $100 \mathrm{mM}$ sodium citrate ( $\mathrm{pH}$ 5.5). Proteolytic activity was inhibited by the addition of $5 \mu$ l of PMSF $(0.2$ $\mathrm{M})$. Samples were incubated in the presence and absence of $10 \mathrm{mu}$ endo $\mathrm{H}$ for four hours at $37^{\circ} \mathrm{C}$ and dissolved in SDS buffer (Laemmli, 1970) for 1 min at $95^{\circ} \mathrm{C}$ prior to electrophoresis.

\section{Results}

\section{Identification and characterisation of proteins in buman cardiac sarcoplasmic reticulum using mono- clonal and poly clonal antibodies}

Immunoblot staining of human cardiac sarcoplasmic reticulum with a monoclonal antibody to the $\mathrm{Ca}^{2+}$-transporting ATPase of canine cardiac sarcoplasmic reticulum demonstrated the presence of an antigenicallyrelated protein in human preparations (Fig. 1). The apparent molecular weight of the human protein was $105000-\mathrm{Da}$, slightly larger than that of the canine form. The antibody did not cross-react with the $\mathrm{Ca}^{2+}$ transporting ATPase of skeletal muscle, a separate gene product. Phospholamban was identified in human cardiac sarcoplasmic reticulum using a monoclonal antibody to its canine and bovine forms (Fig. 1). When solubilized at room temperature, the human protein migrated on SDS polyacrylamide gels predominantly with an apparent molecular weight of $29000-\mathrm{Da}$, slightly higher than that of the canine form. Another band migrating with an apparent molecular weight of 7000 $\mathrm{Da}$ was also present in both human and canine preparations. When human or canine sarcoplasmic reticulum was solubilized at 


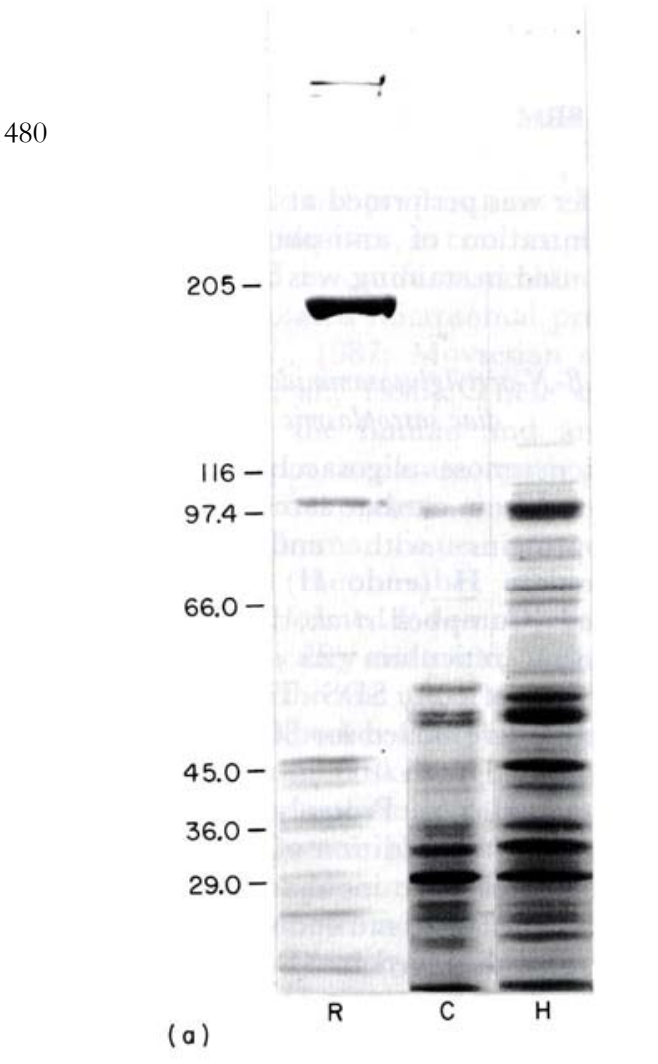

(a)
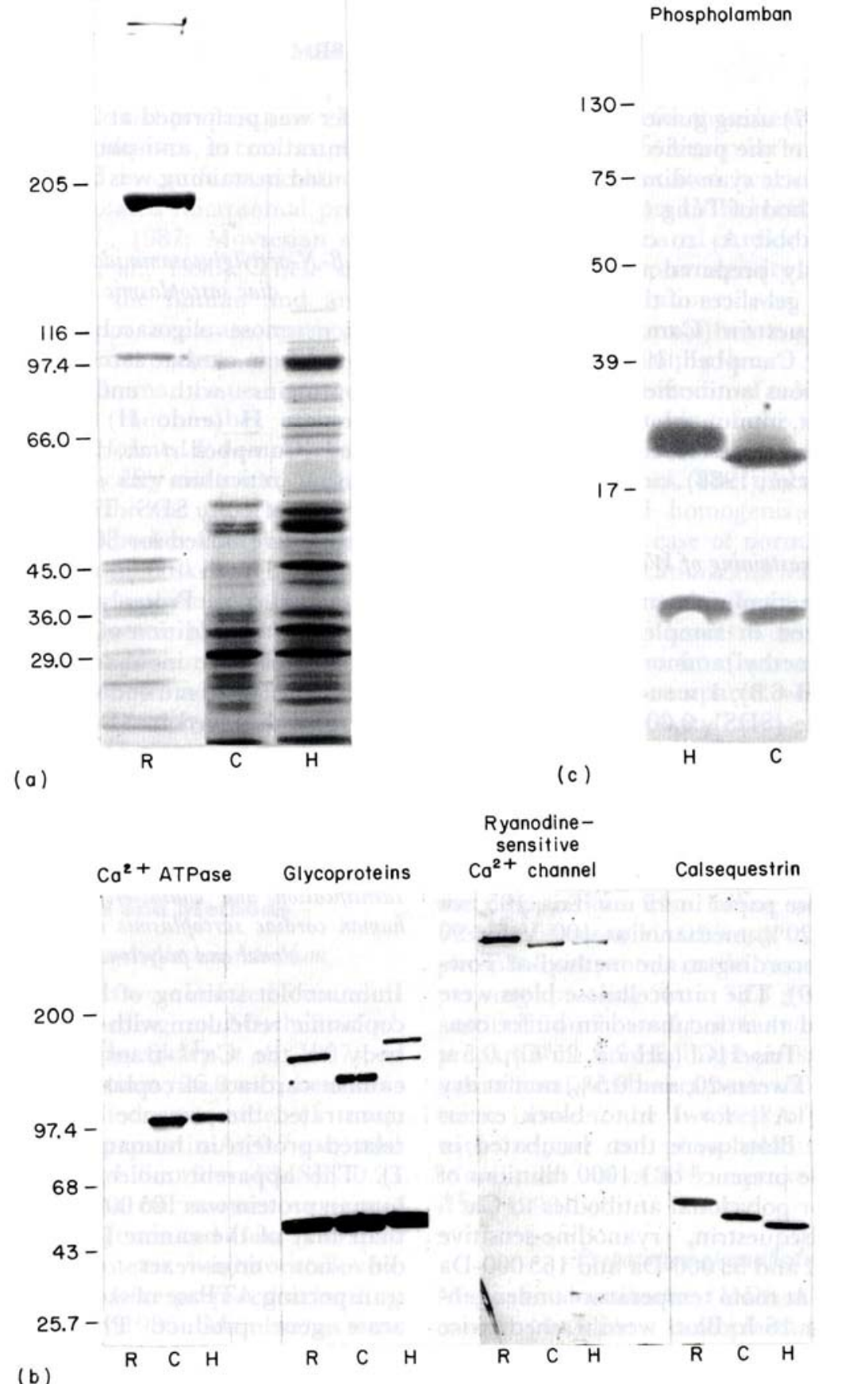

FIGURE 1. Comparison of rabbit skeletal, canine cardiac, and human cardiac sarcoplasmic rericulum. (a) Protein samples $(20 \mu \mathrm{g} /$ lane) from rabbit skeletal muscle triads (R), canine cardiac muscle triads (C), and human cardiac microsomes $(\mathrm{H})$ were electrophoresed through SDS-polyacrylamide gradient gels $(3-12 \%)$ and stained with Coomassie blue. Molecular weights $\left(\times 10^{-3}\right)$ are indicated at left; (b) Proteins electrophoresed through SDS-polyacrylamide gels were transferred electrophoretically to nitrocellulose and immunoperoxidase-stained using monoclonal antibody IID8 (anti-Ca ${ }^{2+}$ ATPase), monoclonal antibody XIIC4 (anti-glycoprotein), polyclonal antibody GP-3 (anti-ryanodinesensitive $\mathrm{Ca}^{2+}$ channel), and polyclonal antibody rabbit A (anti-calsequestrin). Proteins per lane were:

$\begin{array}{lrrr} & \text { Rabbit } & \text { Canine } & \text { Human } \\ \text { anti-Ca }{ }^{2+} \text { ATPase } & 5 \mu \mathrm{g} & 5 \mu \mathrm{g} & 5 \mu \mathrm{g} \\ \text { anti-glycoproteins } & 10 \mu \mathrm{g} & 10 \mu \mathrm{g} & 30 \mu \mathrm{g} \\ \text { anti-Ca }{ }^{2+} \text { channel } & 5 \mu \mathrm{g} & 60 \mu \mathrm{g} & 60 \mu \mathrm{g} \\ \text { anti-calsequestrin } & 5 \mu \mathrm{g} & 5 \mu \mathrm{g} & 5 \mu \mathrm{g}\end{array}$

(c) $20 \mu \mathrm{g}$ samples of human and canine cardiac sarcoplasmic reticulum were electrophoresed, transferred electrophoretically to nitrocellulose and immunoperoxidase-stained using monoclonal antibody $\mathrm{Al}$ (anti-phospholamban). 
$95^{\circ} \mathrm{C}$, however, only the $7000-\mathrm{Da}$ form was present (data not shown). These findings are consistent with the heat-induced pentamermonomer shift of phospholamban.

A monoclonal antibody to the 53000 - and 160 000-Da glycoproteins of rabbit skeletal muscle sarcoplasmic reticulum and the 53000 - and 130 000-Da glycoproteins of canine cardiac sarcoplasmic reticulum also cross-reacted with proteins in human cardiac preparations (Fig. 1). The major species identified in human cardiac sarcoplasmic reticulum migrated with an apparent molecular weight of $53000-\mathrm{Da}$, indistinguishable from that of its counterparts in rabbit skeletal and canine cardiac sarcoplasmic reticulum. The antibody also cross-reacted with two higher molecular weight species in human cardiac sarcoplasmic reticulum, one of which migrated with an apparent molecular weight of $165000-\mathrm{Da}$ and the other with an apparent molecular weight of $155000-\mathrm{Da}$. To establish that the species identified by this antibody in human cardiac sarcoplasmic reticulum were glycoproteins, vesicle preparations were treated with endo $\mathrm{H}$ prior to electrophoresis, transfer and immunostaining (Fig 2). The apparent molecular weights of the three glycoprotein bands were all reduced by 4 000-5 000-Da by this treatment. This effect is comparable to that seen in rabbit skeletal and canine cardiac sarcoplasmic reticulum, and confirms that the immunostained bands in human cardiac sarcoplasmic reticulum are glycoproteins with mannose-containing oligosaccharide side chains (Campbell and MacLennan, 1981; Campbell et al., 1983). The magnitude of the mobility shifts also made clear that the $155000-\mathrm{Da}$ band in human cardiac sarcoplasmic reticulum was not generated by cleavage of the glyco-peptide bond of the 165 000-Da glycoprotein.

Finally, polyclonal antibodies were used to identify and characterize the ryanodinesensitive $\mathrm{Ca}^{2+}$ channel and calsequestrin in human cardiac sarcoplasmic reticulum (Fig. 1). The apparent molecular weight of the human cardiac ryanodine receptor was approximately $400000-\mathrm{Da}$, slightly less than that of the rabbit skeletal muscle form but essentially identical to that of the canine cardiac form. Human cardiac calsequestrin migrated with an apparent molecular weight

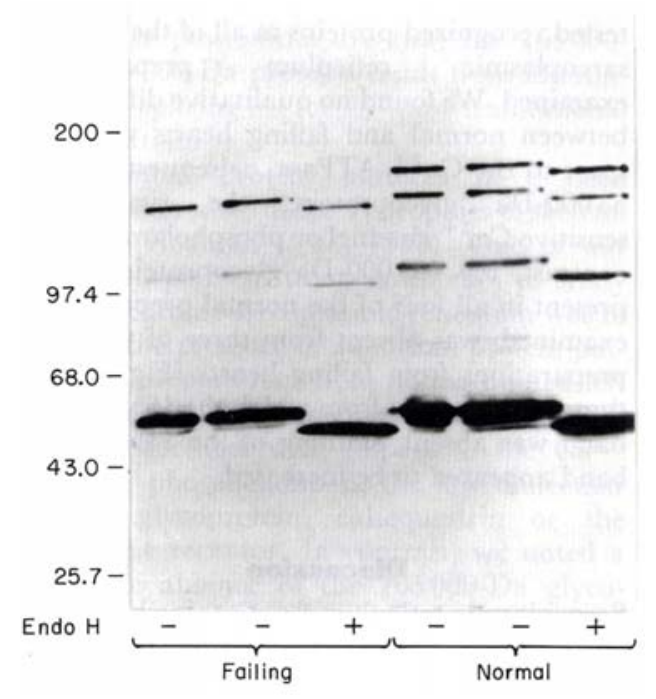

FIGURE 2. Effect of endo $\mathrm{H}$ treatment on failing and normal human heart sarcoplasmic reticulum glycoproteins. Samples of human cardiac sarcoplasmic reticulum were subjected to endo $\mathrm{H}$ treatment as described in "Methods". Samples were then subjected to electrophoresis on a $3-12 \%$ polyacrylamide gel, transferred electrophoretically to nitrocellulose, and stained with monoclonal anti-glycoprotein antibody (XIIC4). The three lanes at left contain sample from one of the patients with idiopathic dilated cardiomyopathy in whom the 165000-Da band was absent (see below in "Results"), and the three lanes at right contain one of the normal samples. In each set, the first lane contains original sample, the second control-treated sample and the third endo $\mathrm{H}$-treated sample. Each lane contains $25 \mu \mathrm{g}$ of protein. Molecular weights $\left(\times 10^{-3}\right)$ are indicated on the left.

of 52000-Da, lower than those of the rabbit skeletal $(63000-\mathrm{Da})$ or canine cardiac (55 000-Da) forms.

\section{Comparison of protein patterns in normal and failing buman beart}

To determine whether qualitative differences might exist between normal and failing human hearts with respect to their protein constituents, we compared immunoblots of left ventricular sarcoplasmic reticulum prepared from the normal left ventricles of unmatched organ donors and the excised failing left ventricles of patients with idiopathic dilated cardiomyopathy. The antibodies 
tested recognized proteins in all of the human sarcoplasmic reticulum preparations examined. We found no qualitative differences between normal and failing hearts with respect to the $\mathrm{Ca}^{2+}$ ATPase, calsequestrin, the 53000-Da glycoprotein, the ryanodinesensitive $\mathrm{Ca}^{2+}$ channel or phospholamban. In contrast, the 165000-Da glycoprotein band, present in all four of the normal preparations examined, was absent from three of the nine preparations from failing hearts (Fig. 3). In those preparations from which the $165000-\mathrm{Da}$ band was absent, staining of the 155 000-Da band appeared to be increased.

\section{Discussion}

Sarcoplasmic reticulum from canine heart has been studied extensively, and several of its protein constituents have been identified and characterized. Among these are a 105 000-Da $\mathrm{Ca}^{2+}$-transporting ATPase (Brandl et al., 1986, 1987); phospholamban, a 2700029 000-Da pentamer whose phosphorylation is associated with stimulation of $\mathrm{Ca}^{2+}$ uptake (Kirchberger et al., 1974; Tada et al., 1974); calsequestrin, a $55000-\mathrm{Da}$ protein that binds $\mathrm{Ca}^{2+}$ within the sarcoplasmic reticulum with low affinity and high capacity (Campbell et al., 1983); two glycoproteins, 53000-Da and 130 000-Da, whose functions remain unknown but which may be involved in intraluminal $\mathrm{Ca}^{2+}$-binding and regulation of $\mathrm{Ca}^{2+}$ uptake (Campbell et al., 1983; Campbell and MacLennon 1981, Campbell and MacLennan, 1983; Pepper et al., 1985; Helmke and Howard, 1987; Leberer et al., 1989a; Leberer et al., 1989b; Kutchai and Campbell, 1989); and a 400000-Da ryanodine-sensitive $\mathrm{Ca}^{2+}$ channel (Lai et al., 1988; Innui et al., 1987; Campbell et al., 1987; Smith et al., 1988). The $\mathrm{Ca}^{2+}$-transporting ATPase of cardiac sarcoplasmic reticulum, like phospholamban, is the product of a gene expressed in cardiac and slow-twitch skeletal muscle but not in fast-twitch skeletal muscle (whose sarcoplasmic reticulum $\mathrm{Ca}^{2+}$ ATPase is the product of a separate gene; Brandl et al., 1986). Calsequestrin is also the product of two separate genes, one of which predominates in fast- and slow-twitch skeletal muscle and the other of which predominates in cardiac muscle (Fliegel et al., 1989).

Less is known regarding the genetics of the other sarcoplasmic reticulum proteins. The 53000 - and 160 000-Da glycoproteins of rabbit fast-twitch skeletal muscle sarcoplasmic reticulum have been shown to be alternatesplice products of the same gene (Leberer et al., 1989b). Whether the same applies to the corresponding glycoprotein of cardiac muscle sarcoplasmic reticulum is uncertain, but the

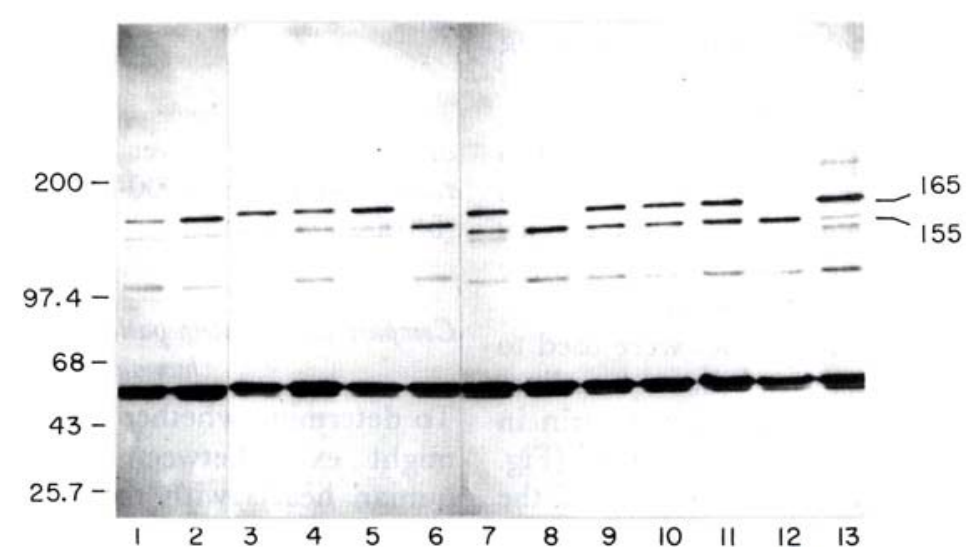

FIGURE 3. Identification of proteins in sarcoplasmic reticulum from normal and failing heart. Samples of sareoplasmic reticulum were electrophoresed through SDS-polyacrylamide gels (3-12\%) and transferred electrophoretically to nitrocellulose. Nitrocellulose transfers were stained with monoclonal anti-glycoprotein (XIIC4). Molecular weights $\left(\times 10^{-3}\right)$ are indicated on the left. Lanes 1-4 contained samples from normal hearts and lanes 5-13 contained samples from failing hearts. 
cross-reactivity of the monoclonal antibody used in these experiments would make this seem likely. The genetics of the ryanodinesensitive $\mathrm{Ca}^{2+}$ channel, whose cardiac and skeletal muscle forms are similar in apparent molecular weight and channel properties (Lai et al., 1988; Inui et al., 1987; Anderson et al., 1989), remain undefined. Significant differences in the ryanodine-binding properties of cardiac and skeletal muscle sarcoplasmic reticulum have been noted, raising the possibility that the cardiac and skeletal muscle proteins are products of separate genes or are alternate-splice or post-translationally modified products of the same gene. These differences might just as plausibly result from differences in the molecular environments of the ryanodine receptor in cardiac and skeletal muscle sarcoplasmic reticulum. Our results do not exclude any of these possibilities.

In the experiments described in this paper, we have used immunochemical methods to characterize the major proteins of human cardiac sarcoplasmic reticulum. The apparent molecular weights of the human cardiac forms of the $\mathrm{Ca}^{2+}$ ATPase, ryanodine-sensitive $\mathrm{Ca}^{2+}$ channel, calsequestrin, phospholamban and the low molecular weight glycoprotein were similar to those of their canine counterparts. More striking differences were seen with respect to the high molecular weight glycoproteins. Two high molecuair weight glycoprotein bands were identified in humans, whereas only one high molecular weight glycoprotein band was identified in canine cardiac preparations. In addition, the human cardiac glycoproteins had apparent molecular weights 25000 - to $35000-\mathrm{Da}$ higher than that of the corresponding canine cardiac glycoprotein. The reason for these differences is not obvious. One possibility is that the $155000-\mathrm{Da}$ protein, whose staining appeared increased in samples from which the $165000-\mathrm{Da}$ band was absent, might be a shorter proteolytic derivative of the 165 000-Da glycoprotein (as shown in Fig. 2, it did not result from cleavage of the glycopeptide bond of the 165 000-Da glycoprotein). The high molecular weight glycoprotein of skeletal muscle is an intralumenal protein resistant to proteolysis in intact vesicles, however. If this property is shared by its human cardiac counterparts, proteolysis of the 165 000-Da glycoprotein would seem less like- ly. Other possibilities are that the 165000and $155000-\mathrm{Da}$ proteins result from alternative splicing or post-translational modification.

Abnormal protein patterns have been identified in some of the dystrophies of skeletal muscle (Hoffman et al., 1988). One of our major purposes in using antibodies to study human cardiac sarcoplasmic reticulum was to test for the presence of abnormal protein patterns in preparations from failing dilated left ventricles. Our experiments revealed no qualitative differences with respect to the $\mathrm{Ca}^{2+}$ ATPase, phospholamban, the low molecular weight glycoprotein, calsequestrin or the ryanodine receptor. In contrast, we noted a complete absence of the $165000-\mathrm{Da}$ glycoprotein band and an accompanying increase in the $155000-\mathrm{Da}$ glycoprotein band in three of the nine preparations from failing hearts. The absence of the 165000-Da band might therefore reflect increased proteolysis in affected hearts. None of the other proteins examined showed any qualitative differences in susceptibility to proteolysis in preparations from normal and failing heart, however. For this reason, and for the reasons noted earlier, we regard this explanation as less likely.

Does the absence of the 165000-Da glycoprotein band identify or reflect a pathogenetic mechanism in a subset of humans with idiopathic dilated cardiomyopathy? The possibility is intriguing, but until more is learned about the $165000-\mathrm{Da}$ and $155000-\mathrm{Da}$ glycoproteins consideration must remain speculative. The high molecular weight glycoprotein of skeletal muscle has recently been shown to be a $\mathrm{Ca}^{2+}$ binding protein localized to the lumen of the longitudinal sarcoplasmic reticulum. Abnormalities involving this protein might therefore be expected to affect $\mathrm{Ca}^{2+}$ sequestration in vivo. The reason for the absence of this protein in three of the nine failing ventricles is not certain, and it would be difficult to propose altered genetic mechanisms involving a gene that has not been characterized in cardiac muscle. Finally, the number of preparations examined was too small to allow predictions of incidence. Improvements in the donor-recipient matching efficiency of organ transplantation networks have resulted in a decrease in the availability of normal human myocardium in quantities 
sufficient for sarcoplasmic reticulum preparations, making it unlikely that the scope of experiments using this methodology can be expanded to any great degree. Further answers may have to wait until 155000- and 165 000-Da glycoprotein messenger RNA levels can be measured in normal and failing human hearts.

\section{Acknowledgements}

We acknowledge the expert technical as- sistance of Joseph Snook of Dr Campbell's laboratory. These studies were supported in part by an operating grant from the Canadian Heart Foundation. John Colyer is the recipient of a Canadian Heart Foundation Fellowship. Jerry H. Wang is an Alberta Heritage Foundation for Medical Research Scientist. Kevin P. Campbell is an Investigator of the Howard Hughes Medical Institute and the recipient of National Institute of Health grants HL-14388 and HL-39265.

\section{References}

ANderson, K., LAi, F. A., LiU, Q.-Y., Rousseau, E., Erickson, H. P., Meissner, G. (1989) Structural and functional characterization of the purified cardiac ryanodine receptor- $\mathrm{Ca}^{2+}$ channel complex. J Biol Chem 264: 1329-1335.

Brandl, C.J., Green, N. M., KorCZAK, B., Maxlennan, D. H. (1986) Two Ca ${ }^{2+}$ ATPase genes: homologies and mechanistic implication of deduced amino acid sequences. Cell 44: 597-607.

Brandl, C. J., De Leon, S., Martin, D. R., Maclennan, D. H. (1987) Adult forms of the $\mathrm{Ca}^{2+}$ ATPase of sarcoplasmic reticulum. J Biol Chem 262: 3768-3774.

CAmpBell, K. P., MACLENnAn, D. H. (1981) Purification and characterization of the 53000 Dalton glycoprotein from the sarcoplasmic reticulum. J Biol Chcm 256: 4626-4632.

CAMPBELL, K. P., MACLENNAN, D. H. (1983) Labeling of high-affinity ATP binding sites on the 53000 and 160000 Dalton glycoproteins of the sarcoplasmic reticulum with the photoaffinity probe $8-\mathrm{N}_{3}(\alpha-32 \mathrm{P})$-ATP.J Biol Chem 258 : 1391-1394.

Campbell, K. P., Maclennan, D. H.Jorgensen, A. O., Mintzer, M. C. (1983) Purification and characterization of calsequestrin from canine cardiac sarcoplasmic reticulum and identification of the 53000 dalton glycoprotein. J Biol Chem 258: 1197-1204.

Campbell, K. P., Knudson, C. M., Imagawa, T., Leung, A. T., Sutko, J. L., Kahl, S. D., RaAB, C. R., Madson, L. (1987) Identification and characterization of the high affinity $\left[{ }^{3} \mathrm{H}\right]$ Ryanodine receptor of the junctional sarcoplasmic reticulum $\mathrm{Ca}^{2+}$ channel. J Biol Chem 262: 6460-6463.

Fuegel, L., Leberer, E., Green, N. M., Maclennan, D. H. (1989) The fast-twitch muscle calsequestrin isoform predominates in rabbit slow-twitch soleus muscle. FEBS Lett 242: 297-300.

Gwathmey, J. K., Copelas, L., MacKinnon, R., Schoen, F. J., Feldman, M. D., Grossman, W., Morgan, J. P. (1987) Abnormal intracellular calcium handling in myocardium from patients with end-stage heart failure. Circ Res 61: 70-76.

HelmKe, S. M., HOWARD, B. D. (1987) Fractionation and reconstitution of the sarcoplasmic reticulum $\mathrm{Ca}^{2+}$ pump solubilized and stabilized by CHAPS/lipid micelles. Membr Biochem 7: 1-22.

Hoffman, E. P., KNUdSON, C. M., CAMPBELl, K. P., KUnKEL, L. M. (1987) Subcellular fractionation of dystrophin as a component of triads. Nature 330: 754-758.

HOFFMAN, E. P., FisCHBECK, K. H., Brown, R. H., JOHNSON, M., MEDORI, R., LOIKE, J. D., HARRis, J. B., WATERSTON, R., Brooke, M., Specht, L., Kupsky, W., Chamberlain, J., Caskey, C. T., Shapiro, F., Kunkel, L. M. (1988) Characterization of dystrophin in muscle-biopsy specimens from patients with Duchenne's or Becker's muscular dystrophy. N Engl J Med 318: 1363-1368.

INUI, M., SAITO, A., FLEISCHER, S. (1987) Isolation of the ryanodine receptor from cardiac sarcoplasmic reticulum and identity with the feet structures. J Biol Chem 262: 15637-15642.

JONES, L. R., GALA, S. E. (1981) Biochemical evidence for functional heterogeneity of cardiac sarcoplasmic reticulum vesicles. J Biol Chem 256: 11809-11818.

Jorgensen, A. O., CAMPBELL, K. P. (1984) Evidence for the presence of calsequestrin in two structurally different regions of myocardial sarcoplasmic reticulum. J Cell Biol 98: 1597-1602.

Jorgensen, A. O., Arnold, W., Pepper, R., Kahl, S. D., CAmpbell, K. P. (1984) A monoclonal antibody to the $\mathrm{Ca}^{2+}$-ATPase of cardiac sarcoplasmic reticulum crossreacts with type I (slow) but not type II (fast) skeletal muscle fibers. Cell Motility and the Cytoskeleton 9: 164-174.

Kirchberger, M. A., TADA, M., KATZ, A. M. Adenosine (1974) 3':5'-monophosphate-dependent protein kinasecatalyzed phosphorylation reaction and its relationship to calcium transport in cardiac sarcoplasmic reticulum. J Biol Chem 249: 6166-6173.

KUTCHAI, H., CAMPBELL, K. P. (1989) Calcium transport by sarcoplasmic reticulum of skeletal muscle is inhibited by antibodies against the $53 \mathrm{KDa}$ glycoprotein of the sarcoplasmic reticulum membrane. Biochemistry 28: 4830-4839.

LAEMMLI, U. K. (1970) Cleavage of structural proteins during the assembly of the head of bacteriophage T4. Nature (Lond) 227: 680-685. 
Lai, F. A., Anderson, K., Rousseau, E., LiU, Q.-Y., Meissner, G. (1988) Evidence for a $\mathrm{Ca}^{2+}$ channel within the ryanodine receptor complex from cardiac sarcoplasmic reticulum. Biochem Biophys Res Commun 151: 441-449 (1988). Leberer, E., Charuk, J. H. M., Clarke, D. M., Green, N. M., Zubrzycka-Gaarn, E., MacLennan, D. H. (1989a) Molecular cloning and expression of cDNA encoding the 53000-dalton glycoprotein of rabbit skeletal muscle sarcoplasmic reticulum. J Biol Chem 264: 3484-3493.

Leberer, E., Charuk, J. H. M., Green, N. M., MacLennen, D. H. (1989b) Molecular cloning and expression of cDNA encoding a lumenal calcium binding glycoprotein from sarcoplasmic reticulum. Proc Natl Acad Sci 86: 6047-6051.

Leung, A. T., Imagawa, T., Block, B., Franzini-Armstrong, C., CAmpBell, K. P. (1988) Biochemical and ultrastructural characterization of the 1-4-dihydropyridine receptor from rabbit skeletal muscle: evidence for a 52000 Da subunit. J Biol Chem 263: 944-1001 .

Limas, C. J., Olivari, M. T., Goldenberg, I. F., Levine, T. B., Benditit, D. G., SimON, A. (1987) Calcium uptake by cardiac sarcoplasmic reticulum in human dilated cardiomyopathy. Cardiovasc Res 21: 601-605.

Mitchell, R. D., PALAde, P., Fleischer, S. (1983) Purification of morphologically intact triad structures from skeletal muscle. J Cell Biol 96: 1008-1016.

MOVSESIAN, M. A., BRISTOW, M. R., KRALL, J. (1989) Calcium uptake by cardiac sarcoplasmic reticulum from patients with idoiopathic dilated cardiomyopathy. Circ. Res 65: 1141-1144.

Movsesian, M. A., Colyer, J., WAnG, J. H., KRAll, J. (1990) Phospholamban-mediated stimulation of $\mathrm{Ca}^{2+}$ uptake in cardiac sarcoplasmic reticulum from normal and failing human hearts. J Clin Invest 85: 1698-1702.

PePpeR, D. R., RAAB, C. R., CAMPBELl, K. P. (1985) Identification and characterization of $53000 \mathrm{Da}$ and $160000 \mathrm{Da}$ glycoproteins and the $\mathrm{Ca}^{2+}$-ATPase of sarcoplasmic reticulum in red and white skeletal, smooth and cardiac muscles. Biophys J 47: 344a.

Sharp, A. H., Imagawa, T., Leung, A. T., CAmpbell, K. P. (1987) Identification and characterization of the dihydropyridine-binding subunit of the skeletal muscle dihydropyridine receptor. J Biol Chem 262: 12309-12315.

Smith, J. S., Imagawa, T., MA, J., Fill, M., CAMPBell, K. P., CORONADO, R. (1988) Purified ryanodine receptor from rabbit skeletal muscle is the calcium channel of sarcoplasmic reticulum. J Gen Physiol 92: 1-26.

SUZUKI, T., WANG, J. H. (1986) Stimulation of bovine cardiac sarcoplasmic rericulum $\mathrm{Ca}^{2+}$ pump and blocking of phospholamban phosphorylation and dephosphorylarion by a phospholamban monoclonal antibody. J Biol Chem 261: 7018-7023.

TADA, M., Kirchberger, M. A., Repke, D. I., KATZ, A. M. (1974) The stimulation of calcium transport in cardiac sarcoplasmic rericulum by adenosine 3':5'-monophosphate-dependent protein kinase.J Biol Chem 249: 6174-6180.

TOWBIN, H., STAEHUN, T., BORDON, J. (1979) Electrophoretic transfer of proteins from polyacrylamide gels to nitrocellulose sheets: procedure and some applications. Proc Natl Acad Sci 76: 4350-4354.

Tung, A. S. (1983) Production of large amounts of antibodies, nonspecific immunoglobins, and other serum proteins in asicric fluids of individual mice and guinea pigs. Methods Enzymol 93: 12-23.

WhitMer, J. T., KUMAR, P., SOLARO, R.J. (1988) Calcium transport properties of cardiac sarcoplasmic rericulum from cardiomyopathic Syrian hamsters (BIO 53.58 and 14.6): evidence for a quantitative defect in dilated myopathic hearts not evident in hypertrophic hearts. Circ Res 62: 81-85. 